Biogen, BMS, Boehringer, Celgene, Celltrion, Centocor, Chugai, Hexal, Janssen, Lilly, Medac, MSD (Schering-Plough), Mylan, Mundipharma, Novartis, Pfizer (Wyeth, Hospira), Roche, Sanofi-Aventis and UCB, Consultant for: AbbVie, BMS, Celgene, Chugai, Merck, Novartis, Pfizer, UCB, Consultant for: Abbott, Bristol Myers Squibb, Celgene, Celltrion, Chugai, Johnson \& Johnson, MSD, Novartis, Pfizer, Roche, UCB Pharma, Speakers bureau: AbbVie, BMS, Celgene, Chugai, Merck, Novartis, Pfizer, UCB, Speakers bureau: Abbvie (Abbott), Amgen, Baxter, Biogen, BMS, Boehringer, Celgene, Celltrion, Centocor, Chugai, Hexal, Janssen, Lilly, Medac, MSD (Schering-Plough), Mylan, Mundipharma, Novartis, Pfizer (Wyeth, Hospira), Roche, Sanofi-Aventis and UCB, Speakers bureau: AbbVie, BMS, Celgene, Chugai, Merck, Novartis, Pfizer, UCB, Weibin Bao Employee of: Novartis, Brian Porter Shareholder of: Novartis, Employee of: Novartis, Effie Pournara Shareholder of: Novartis, Employee of: Novartis

DOI: 10.1136/annrheumdis-2019-eular.1834

\section{FRI0419 OUTCOMES OF DOSE REDUCTION OF TNF-INHIBITORS IN AXIAL SPONDYLOARTHRITIS AT 24 MONTHS}

$\underline{\text { Liz Van Rossen }}{ }^{1}$, Claire Harris ${ }^{2}$, Annie Gilbert ${ }^{3}$, Raj Sengupta ${ }^{4}$, Cathal Boyle ${ }^{4}$, Karl Gaffney ${ }^{5}$, Pedro Machado ${ }^{2}$, Andrew Keat ${ }^{2}$. 'East Kent Hospital University Foundation Trust, Canterbury, United Kingdom; ${ }^{2}$ Northwick Park Hospital, London, United Kingdom; ${ }^{3}$ AKGilbertltd, Brighton, United Kingdom; ${ }^{4}$ Royal National Orthopaedic Hospital, Bath, United Kingdom; ${ }^{5}$ Norfolk and Norwich Hospital, Norfolk, United Kingdom

Background: Some patients with inflammatory arthritis who respond well to TNF inhibitor (TNFi) treatment continue to do so after dose reduction. In Axial Spondyloarthritis (axSpA) dose optimisation is desirable but the extent of benefit is unclear and predictors of therapeutic response to dose reduction are unknown.

Objectives: To observe responses to dose reduction of TNFi treatment in axSpA patients and to seek preliminary predictors of low-dose therapeutic response.

Methods: AxSpA Patients at 4 UK centres were allowed to reduce their doses of TNFi therapy if they had met UK (NICE) response criteria and remained well for at least 6 months and wished to do so. There was no predetermined dose-reduction schedule. The proportion of dose reduction was calculated as a percentage, in mg per month, of the original, standard dose. All patients completed BASDAI and BASFI questionnaires at each visit with annual BASMI measurement. CRP levels were measured frequently. Individuals who continued to take reduced-dose treatment throughout the 24-month period were designated "Remainers" (REM) and those who reverted to full-dose treatment were designated "Reverters" (REV). Data were collected at 6 timepoints; 1 : immediately before starting TNFi therapy; 2: at the point of dose reduction; 3 : at the point of reversion to full-dose treatment (REV only); 4: 6 months after dose reduction; 5:12 months after dose reduction; 6: 24 months after dose reduction.

Results: 58 patients (86\%male) who had reduced their dose of TNFi treatment were observed for 24 months. 47 (81\%) were REM and 11 (19\%) were REV. Mean disease duration prior to biologic therapy was 22.6 years for remainers and 18.6 years for reverters. Mean dose reduction was $38 \%$ and $41 \%$, respectively. These 47 REM ( $85 \%$ male) were of mean age 53.6 (range 36 to 71 ) years, compared with the 11 REV (63.6\% male) whose mean age was 51.9 (range 39 to 71 ) years.

Mean BASDAI, BASFI and BASMI scores and CRP levels at the designated time points are shown in table1.

REM mean BASDAI scores reduced from 1.9 to 1.4 (28\%) from dose reduction to 24 months whereas REV mean BASDAl scores increased from 1.8 to 2.4 (34\%) from dose reduction to dose reversion.

REM mean BASFI scores reduced from 2.5 to 1.4 (43\%) from dose reduction to 24 months whereas REV mean BASFI scores increased from 2.6 to $3.0(17 \%)$ from dose reduction to dose reversion.

REM mean BASMI scores reduced from 3.4 to 2.3 (32\%) from dose reduction to 24 months whereas REV mean BASMI scores increased from 2.8 to $3.3(19 \%)$ from dose reduction to dose reversion.

REM mean CRP scores decreased from 4.1 to $0.7 \mathrm{mg} / \mathrm{dl}$ (83\%) from dose reduction to 24 months and REV mean CRP scores also decreased from 4.7 to $3.5 \mathrm{mg} / \mathrm{dl}$ (25\%) from dose reduction to dose reversion.

Conclusion: Amongst these selected patients with axSpA $85 \%$ continued to respond to TNFi treatment in spite of $38 \%$ dose reduction. Reverters were more likely to be female and to have relatively low CRP levels at the initiation of TNFi treatment; reversion was preceded by modest rises in BASDAI, BASFI and BASMI but by continued fall in CRP levels.
There is a need for randomised dose-reduction studies in axSpA and further research to understand the factors that lead to dose-reversion.

Disclosure of Interests: Liz Van Rossen Grant/research support from: UCB, Abbvie, Consultant for: Novartis, Speakers bureau: Abbvie, UCB Novartis, Claire Harris Consultant for: Abbvie, Speakers bureau: Abbvie Annie Gilbert Consultant for: Boehringer, Raj Sengupta Grant/research support from: AbbVie, Celgene Corporation, Merck Sharp \& Dohme, Novartis, Pfizer, and UCB, Speakers bureau: AbbVie, Celgene Corporation, Merck Sharp \& Dohme, Novartis, Pfizer, and UCB, Cathal Boyle: None declared, Karl Gaffney Grant/research support from: Abbvie, Pfizer Consultant for: Abbvie, Lilly, Novartis, UCB, Speakers bureau: Abbvie, Biogen, Gilead, Lilly, Novartis, UCB, Pedro Machado Consultant for: Abbvie, BMS, Celgene, Janssen, MSD, Novartis, Pfizer, Roche and UCB Speakers bureau: Abbvie, BMS, Celgene, Janssen, MSD, Novartis, Pfizer Roche and UCB, Andrew Keat: None declared DOI: 10.1136/annrheumdis-2019-eular.3985

\section{TABLE}

\begin{tabular}{lccccccc}
\hline & No & T/P1 & $\begin{array}{c}\text { T/ } \\
\text { P2 }\end{array}$ & $\begin{array}{c}\text { T/ } \\
\text { P3 }\end{array}$ & $\begin{array}{c}\text { T/ } \\
\text { P4 }\end{array}$ & $\begin{array}{c}\text { T/ } \\
\text { P5 }\end{array}$ & $\begin{array}{c}\text { T/P } \\
6\end{array}$ \\
\hline BASDAI & 47 & 5.8 & 1.9 & n/a & 1.2 & 1.3 & 1.4 \\
REM & & & & & & & \\
REV & 11 & 5.2 & 1.7 & 2.4 & & & \\
BASFI REM & 47 & 4.5 & 2.5 & $\mathrm{n} / \mathrm{a}$ & 1.6 & 1.4 & 1.4 \\
REV & 11 & 4.4 & 2.6 & 3.0 & & & \\
BASMI REM & 47 & 3.9 & 3.4 & $\mathrm{n} / \mathrm{a}$ & 1.8 & 2.0 & 2.3 \\
REV & 11 & 4.0 & 2.7 & 3.3 & & & \\
CRP REM & 47 & 12.8 & 4.1 & $\mathrm{n} / \mathrm{a}$ & 0.8 & 1.4 & 0.7 \\
REV & 11 & 6.7 & 4.7 & 3.5 & & & \\
\hline
\end{tabular}

T/P Timepoint

\section{FRI0420 IXEKIZUMAB SIGNIFICANTLY IMPROVES SELF- REPORTED OVERALL HEALTH IN PATIENTS WITH ACTIVE ANKYLOSING SPONDYLITIS/RADIOGRAPHIC AXIAL SPONDYLOARTHRITIS: SF-36 RESULTS OF TWO PHASE 3 TRIALS}

Jessica A. Walsh ${ }^{1,2}$, Uta Kiltz ${ }^{3,4}$, James Cheng-Chung Wei ${ }^{5}$, Filip van den Bosch ${ }^{6}$, Theresa Hunter $^{7}$, Yan Dong ${ }^{7}$, LI Xiaoqi ${ }^{7}$, David Sandoval ${ }^{7}$, Luis Leon ${ }^{7}$,

Vibeke Strand ${ }^{8} .{ }^{1}$ University of Utah, Salt Lake City, United States of America;

${ }^{2}$ Veterans Affairs Medical Center, Salt Lake City, United States of America;

${ }^{3}$ Rheumazentrum Ruhrgebiet, Herne, Germany; ${ }^{4}$ Ruhr-Universität Bochum, Bochum, Germany, ${ }^{5}$ Chung Shan Medical University Hospital, Taichung City, Taiwan, Republic of China; ${ }^{6}$ Ghent University Hospital, Ghent, Belgium; ${ }^{7}$ Eli Lilly and Company, Indianapolis, United States of America; ${ }^{8}$ Biopharmaceutical Consultant, Portolo Valley, United States of America

Background: Using the Short Form-36 (SF-36) questionnaire, previous studies have determined that ankylosing spondylitis/radiographic axial spondyloarthritis (AS/r-axSpA) significantly impairs patients' health-related quality of life (HRQoL). ${ }^{1}$ Ixekizumab (IXE), a humanized anti-interleukin$17 \mathrm{~A}$ monoclonal antibody, improves disease signs and symptoms in patients with AS/r-axSpA. ${ }^{2,3}$ Week 16 SF-36 results from two clinical trials with IXE are presented here (NCT02696785 and NCT02696798).

Objectives: To evaluate the efficacy of IXE versus placebo (PBO) in improving HRQoL assessed by the SF-36 questionnaire in patients with active AS/r-axSpA who were either naïve to biologic therapy or have failed or been intolerant of one or two TNF inhibitors (TNFi).

Methods: COAST-V and $-\mathrm{W}$ are randomized, double-blind, placebo-controlled clinical trials. Enrolled patients were adults with active AS/r-axSpA classified by ASAS criteria who fulfilled $\mathrm{mNY}$ of sacroiliitis (central reading), with Bath Ankylosing Spondylitis Disease Activity Index (BASDAI) and back pain $\geq 4$. In COAST-V, patients naïve to biologic agents were randomized $1: 1: 1: 1$ to receive $80 \mathrm{mg}$ IXE every 4 weeks (Q4W), $80 \mathrm{mg}$ IXE every 2 weeks (Q2W), adalimumab $40 \mathrm{mg}$ Q2W (ADA), or PBO. In COAST-W, patients who had failed on or were intolerant of one or two TNFi were randomized 1:1:1 to $80 \mathrm{mg}$ IXE Q4W, $80 \mathrm{mg}$ IXE Q2W, or PBO. In both studies, patients in the IXE arms were randomized to receive either $80 \mathrm{mg}$ or $160 \mathrm{mg}$ IXE as the starting dose. Comparisons of change from baseline to Week 16 in norm-based SF-36 scores between active groups and PBO were performed using mixed model for repeated measures. 
Figure. Change from baseline in SF-36 at 16 weeks in (A.) biologic naïve patients and (B.) TNFi-experienced patients
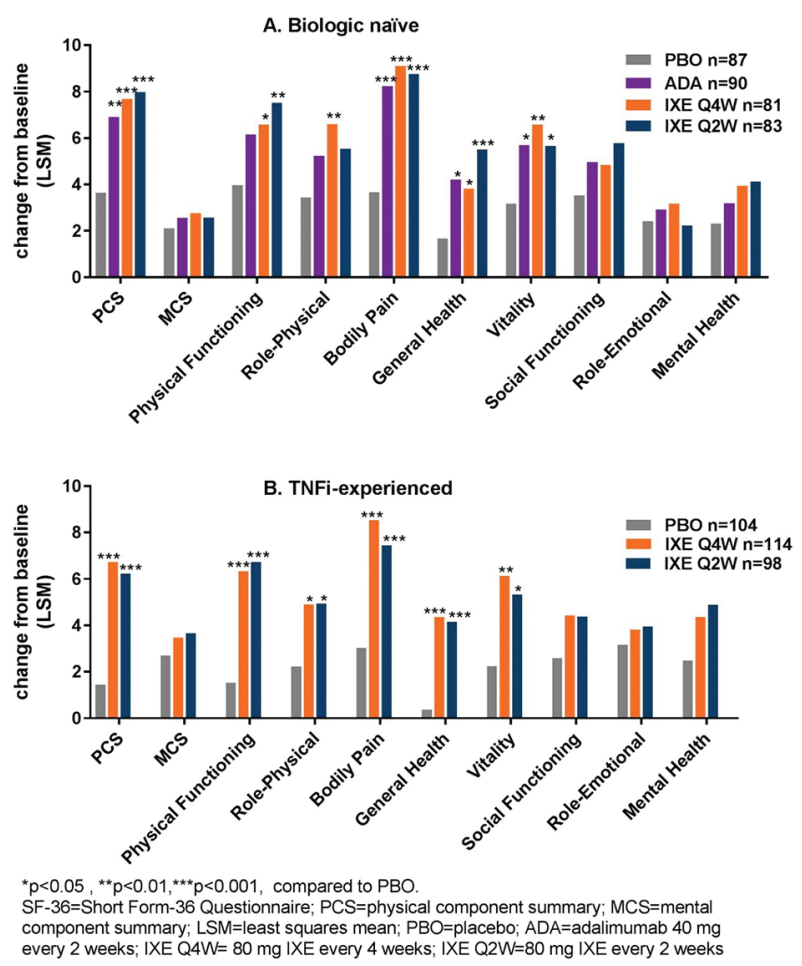

Results: Biologic naïve and TNFi-experienced patients treated with IXE reported significantly greater improvement than PBO patients in SF-36 Physical Component Summary and the physical functioning, bodily pain, general health, and vitality domains. No changes between treatments groups were reported in Mental Component Summary scores. The greatest numerical improvements with IXE were observed in the bodily pain domain. Similar improvements were reported in the IXE Q4W, IXE Q2W, and ADA groups.

Conclusion: IXE improved self-reported HRQoL, as measured by the SF36 questionnaire, at Week 16 in patients with active AS/r-axSpA who were naïve or experienced with biologic treatments.

\section{REFERENCES:}

[1] Yang, et al. (2016). Qual Life Res. 25:2711-23.

[2] van der Heijde, et al. (2018). Lancet. 392(10163):2441-51.

[3] Deodhar, et al. (2018). Arthritis Rheumatol. Doi: 10.1002/art.40753.

Disclosure of Interests: Jessica A. Walsh Grant/research support from: Abbvie, Pfizer, Consultant for: Abbvie, Celgene, Lilly, Novartis, Uta Kiltz Grant/research support from: AbbVie, Chugai, Eli Lilly, Grünenthal, Janssen, MSD, Novartis, Pfizer, Roche, and UCB., Consultant for: AbbVie, Chugai, Eli Lilly, Grünenthal, Janssen, MSD, Novartis, Pfizer, Roche, and UCB., James Cheng-Chung Wei Grant/research support from: Abbvie, BMS, Celgene, Janssen, Novartis, Pfizer, and UCB pharma, Consultant for: TSH Taiwan, Speakers bureau: Janssen, Novartis, Pfizer and TSH, Filip van den Bosch Consultant for: AbbVie, BMS, Galapagos, Janssen, Lilly, Merck, Novartis, Pfizer and UCB, Speakers bureau: AbbVie, BMS, Janssen, Lilly, Merck, Novartis, Pfizer and UCB., Theresa Hunter Employee of: Eli Lilly and Company, Yan Dong Shareholder of: Eli Lilly and Company, Employee of: Eli Lilly and Company, Xiaoqi Li Shareholder of: Eli Lilly and Company, Employee of: Eli Lilly and Company, David Sandoval Shareholder of: Eli Lilly and Company, Employee of: Eli Lilly and Company, Luis Leon Shareholder of: Eli Lilly and Company, Employee of: Eli Lilly and Company, Vibeke Strand Consultant for: AbbVie, Amgen, Bayer, BMS, Boehringer Ingelheim, Celgene, Celltrion, CORRONA, Crescendo, EMD Serono, Genentech/Roche, GSK, Horizon, Inmedix, Janssen, Kezar, Lilly, Merck, Novartis, Pfizer, Regeneron, Samsung, Sandoz, Sanofi, Servier, UCB.

DOI: 10.1136/annrheumdis-2019-eular.1237

\section{FRI0421 \\ IXEKIZUMAB SIGNIFICANTLY REDUCED PAIN, INFLAMMATION, AND FATIGUE IN PATIENTS WITH RADIOGRAPHIC AXIAL SPONDYLARTHRITIS (R- AXSPA)/ANKYLOSING SPONDYLITIS (AS)}

James Cheng-Chung Wei ${ }^{1}$, Xenofon Baraliakos ${ }^{2}$, Theresa Hunter ${ }^{3}$, Baojin Zhu ${ }^{3}$, Rebecca Bolce ${ }^{3}$, Fangyi Zhao ${ }^{3}$, Philip J. Mease ${ }^{4} .{ }^{1}$ Chung Shan Medical University Hospital, Taichung City, Taiwan, Republic of China; ${ }^{2}$ Rheumazentrum Ruhrgebiet Herne, Ruhr University Bochum, Herne, Germany; ${ }^{3}$ Eli Lilly and Company, Indianapolis, United States of America; ${ }^{4}$ Swedish Medical Center/Providence St. Joseph Health, Seattle, United States of America

Background: Chronic pain, inflammation, and fatigue are among the most common symptoms of radiographic axial spondyloarthritis ( $\mathrm{r}$-axSpA)/ankylosing spondylitis (AS). ${ }^{1,2}$ Efficacy data for ixekizumab (IXE), a high affinity monoclonal antibody that selectively targets interleukin-17A,compared to placebo (PBO) in patients with $r$-axSpA have been reported. ${ }^{3,4}$

Objectives: The purpose of this analysis was to evaluate the impact of IXE on pain, inflammation, and fatigue in patients with r-axSpA treated with IXE versus PBO over 16 weeks.

Methods: This was a prespecified analysis from two Phase 3, multicenter, randomized, placebo-controlled studies comparing the efficacy and safety of IXE $80 \mathrm{mg}$ every 2 weeks (Q2W) or every 4 weeks (Q4W) to PBO or reference, adalimumab (ADA), over 16 weeks in biologic-naive (COAST-V; NCT02696785) and to PBO in tumor necrosis factor inhibitor (TNFi)-experienced (COAST-W; NCT02696798) patients with active $r$ axSpA per Assessment of Spondyloarthritis (SpA) international Society (ASAS) criteria (sacroillitis modified New York criteria and $\geq 1$ SpA feature). Patient global, spinal pain, spinal pain at night, and inflammation (average of BASDAI Q5\&6) data were collected at baseline and Weeks $1,2,4,8,12$, and 16. Fatigue Numeric Rating Scale data were collected at baseline, Week 8 , and Week 16. Changes from baseline were analyzed using mixed-effects model of repeated measures.

Results: In biologic-naive (COAST-V) and TNFi-experienced (COAST-W) patients, significant improvements from baseline in patient global, spinal pain, spinal pain at night, and inflammation were observed as early as Week 1 (Table 1, Figure 1). Significant reductions in fatigue as early as Week 8 (first measurement) were seen in patients receiving IXE Q2W and Q4W and maintained up to Week 16 (Table 1; $P<.05$ ).

Table 1. Change from baseline in patient global, inflammation, and fatigue in patients with $r$ axSpA with IXE, ADA, and PBO in biologic-naive (COAST-V) and TNFi-experienced (COAST-W) patients

\begin{tabular}{|c|c|c|c|c|c|c|}
\hline \multirow[b]{2}{*}{ Parameter } & \multirow[b]{2}{*}{ Study } & \multirow[b]{2}{*}{ Week } & \multicolumn{4}{|c|}{$\begin{array}{c}\text { Least Squares Mean (Standard } \\
\text { Error) }\end{array}$} \\
\hline & & & $\begin{array}{l}\text { IXE } \\
\text { Q2W }\end{array}$ & $\begin{array}{l}\text { IXE } \\
\text { Q4W }\end{array}$ & ADA & PBO \\
\hline \multirow[t]{4}{*}{ Patient Global } & $\begin{array}{c}\text { COAST- } \\
\mathrm{V}\end{array}$ & 1 & $\begin{array}{r}-1.3 \\
(0.17)\end{array}$ & $\begin{array}{r}-1.3 \\
(0.18)\end{array}$ & $\begin{array}{c}-1.4 \\
(0.17)\end{array}$ & $\begin{array}{c}-0.6 \\
(0.17)\end{array}$ \\
\hline & & 16 & $\begin{array}{c}-2.8 \\
(0.25)^{\star}\end{array}$ & $\begin{array}{r}-2.5 \\
(0.25)\end{array}$ & $\begin{array}{c}-2.6 \\
(0.24)^{*}\end{array}$ & $\begin{array}{c}-1.4 \\
(0.24)\end{array}$ \\
\hline & $\begin{array}{l}\text { COAST- } \\
\text { W }\end{array}$ & 1 & $\begin{array}{c}-1.3 \\
(0.18)^{*}\end{array}$ & $\begin{array}{c}-1.1 \\
(0.16)\end{array}$ & - & $\begin{array}{c}-0.4 \\
(0.16)\end{array}$ \\
\hline & & 16 & $\begin{array}{c}-2.1 \\
(0.24)^{*}\end{array}$ & $\begin{array}{c}-2.4 \\
(0.22)^{*}\end{array}$ & - & $\begin{array}{l}-0.7 \\
(0.23)\end{array}$ \\
\hline \multirow[t]{4}{*}{$\begin{array}{l}\text { Inflammation (average of } \\
\text { BASDAI Q5/Q6) }\end{array}$} & $\begin{array}{l}\text { COAST- } \\
\mathrm{V}\end{array}$ & 1 & $\begin{array}{c}-1.5 \\
(0.18)^{*}\end{array}$ & $\begin{array}{c}-1.6 \\
(0.18)^{*}\end{array}$ & $\begin{array}{c}-1.4 \\
(0.17)^{*}\end{array}$ & $\begin{array}{l}-0.4 \\
(0.18)\end{array}$ \\
\hline & & 16 & $\begin{array}{c}-2.9 \\
(0.23)^{*}\end{array}$ & $\begin{array}{c}-3.2 \\
(0.24)^{*}\end{array}$ & $\begin{array}{c}-2.7 \\
(0.22)^{*}\end{array}$ & $\begin{array}{l}-1.3 \\
(0.23)\end{array}$ \\
\hline & $\begin{array}{l}\text { COAST- } \\
\mathrm{W}\end{array}$ & 1 & $\begin{array}{c}-1.4 \\
(0.17)^{*}\end{array}$ & $\begin{array}{c}-1.3 \\
(0.15)^{*}\end{array}$ & - & $\begin{array}{c}-0.4 \\
(0.16)\end{array}$ \\
\hline & & 16 & $\begin{array}{c}-2.4 \\
(0.25)^{\star}\end{array}$ & $\begin{array}{c}-2.4 \\
(0.23)^{*}\end{array}$ & - & $\begin{array}{l}-0.7 \\
(0.24)\end{array}$ \\
\hline \multirow[t]{4}{*}{ Fatigue NRS } & $\begin{array}{l}\text { COAST- } \\
\mathrm{V}\end{array}$ & 8 & $\begin{array}{c}-1.7 \\
(0.23)^{\dagger}\end{array}$ & $\begin{array}{r}-2.0 \\
(0.23)\end{array}$ & $\begin{array}{c}-2.1 \\
(0.22)^{*}\end{array}$ & $\begin{array}{c}-0.9 \\
(0.22)\end{array}$ \\
\hline & & 16 & $\begin{array}{c}-2.1 \\
(0.24)^{\dagger}\end{array}$ & $\begin{array}{r}-2.5 \\
(0.24)\end{array}$ & $\begin{array}{c}-2.2 \\
(0.23)^{\dagger}\end{array}$ & $\begin{array}{c}-1.4 \\
(0.23)\end{array}$ \\
\hline & $\begin{array}{l}\text { COAST- } \\
\mathrm{W}\end{array}$ & 8 & $\begin{array}{r}-1.5 \\
(0.23)\end{array}$ & $\begin{array}{c}-1.8 \\
(0.21)^{\star}\end{array}$ & - & $\begin{array}{c}-0.5 \\
(0.22)\end{array}$ \\
\hline & & 16 & $\begin{array}{c}-1.7 \\
(0.25)\end{array}$ & $\begin{array}{c}-2.0 \\
(0.23)^{\star}\end{array}$ & - & $\begin{array}{c}-0.7 \\
(0.24)\end{array}$ \\
\hline
\end{tabular}

ADA, adalimumab; $<<0.01$ Vs PBO; $p<0.05$ vs PBO.

ixekizumab; NRS, Numeric Rating Scale; PBO, placebo; Q2W, every 2 weeks; Q4W, every 4 weeks. 